\title{
PEMBERDAYAAN PENGELOLA TAMAN NARMADA DENGAN POLA ENGLISH-INTEGRATED SERVICE
}

\author{
Arafiq $^{\left.1^{*}\right)}$, Kamaluddin Yusra ${ }^{1)}$, Nur Ahmadi ${ }^{1)}$, Agus Saputra ${ }^{1)}$ \\ ${ }^{1)}$ Fakultas Keguruan dan IImu Pendidikan, Universitas Mataram \\ Jalan Majapahit 62, Mataram 83125, Lombok - Indonesia \\ *)alamat korespondensi: arafiq@unram.ac.id
}

\begin{abstract}
ABSTRAK
Taman Narmada merupakan salah satu obyek wisata sejarah dan budaya di Kabupaten Lombok Barat yang sering dikunjungi oleh wisatawan mancanegara. Oleh karena itu, diperlukan sumber daya yang mendukung, seperti para pengelola yang terampil, terutama dalam berkomunikasi dalam bahasa asing (bahasa inggris). Tujuan dari kegiatan Pengabdian Kepada Masyarakat ini adalah untuk memberikan pendampingan kepada pengelola Taman Narmada dalam memberikan pelayanan kepada pengunjung dengan Pola English-Integrated Service kepada pengelola Taman Narmada, Kabupaten Lombok Barat. Kegiatan ini menjadikan keterampilan berbahasa Inggris sebagai basis dalam melakukan pendampingan dalam rangka memmberikan layanan prima kepada pengunjung, khususnya pengunjung mancanegara. Materi pendampingan mencakupi keterampilan dalam Welcome Tourists, dealing with tickets, Introducing to Tours, Explaining Safety, Rules, dan Etiquette, Showing Places of Interest. Kegiatan Pengabdian Kepada Masyarakat ini dilaksakan dengan metode partisipatif mulai dari perencanaan, pelaksanaan, sampai pada tahap evaluasi. Kegiatan ini diaksanakan dalam dua sesi, yakni sesi teori dan sesi praktek simulasi. Sesi teori dilakukan dengan memberikan materi Bahasa Inggris di kelas agar peserta memiliki pengetahuan yang cukup terkait dengan keterampilam Bahasa Inggris yang mereka butuhkan, sedangkan sesi praktek simulasi dilakukan berdasarkan tugas dan pekerjaan masing-masing peserta. Semua kegiatan berjalan dengan baik sesuai dengan apa yang telah direncanakan. Hasil kegiatan ini menunjukkan bahwa peserta memiliki keinginan untuk meningkatkan kompetensinya, terutama keterampilan berbahasa Inggris dalam rangka memberikan layanan kepada pengunjung, khususnya pengunjung mancanegara. Diakhir kegiatan, secara umum peserta dapat menggunakan Bahasa Inggris dengan baik, terutama, ungkapan-ungkapan Bahasa Inggris, seperti menyapa tamu (welcoming), menangani loket (ticketting), bahkan keterampilan guiding.
\end{abstract}

Kata kunci : English-Integrated Service, Pengelola, Taman Narmada 


\section{PENDAHULUAN}

Narmada merupakan salah satu kecamatan yang berada dibawah pemerintah Kabupaten Lombok Barat (Anonim, 2013). Walaupun tidak seperti daerah/kecamatan lainnya di Pemerintah Kabupaten Lombok Barat sebagai pusat pengembangan pariwisata, namum Kecamatan Narmada memiliki Taman Narmada yang merupakan destinasi penting yang sering dikungjungi oleh wisatawan baik wisatawan lokal maupun wisatawan mancanegara. Dengan letaknnya yang berada di pusat kota, Taman Narmada sangat terkenal karena bisa diakses dengan mudah dari berbagai arah masuk di Pulau Lombok (Anonim, 2016).

Taman Narmada selama ini dijadikan sebagai destinasi yang wajib ada di paket tour-paket tour yang ada di Pulau Lombok. Oleh karena itu Taman Narmada selalu ramai dikungjungi baik oleh wisatwan lokal, nasional, maupun internasional. Keberadaan wisatawan di tempat tersebut mendatangkan keuntungan bagi masyarakat sekitar. Dengan kehadiran wisatawan tersebut, masyarakat dapat membuka lapangan usaha baru yang cukup dan dibutuhkan oleh para wisatawan, misalnya membuka usaha yang menawarkan jasa akomodasi, konsumsi, serta menawarkan produk khas souvenir kepada wisatawan. Hal ini tentu merupakan sebuah berkah bagi masyarakat setempat karena secara ekonomi kegiatan pariwisata di Taman Narmada ini dapat meningkatkan kesejahteraan masyarakat (Arafiq, dkk., 2019).

Keberadaan wisatawan di tempat tersebut mendatangkan keuntungan bagi masyarakat sekitar. Dengan kehadiran wisatawan tersebut, masyarakat dapat membuka lapangan usaha baru yang cukup dan dibutuhkan oleh para wisatawan, misalnya membuka usaha yang menawarkan jasa akomodasi, konsumsi, serta menawarkan produk khas souvenir kepada wisatawan. Hal ini tentu merupakan sebuah berkah bagi masyarakat setempat karena secara ekonomi kegiatan pariwisata di Taman Narmada ini dapat meningkatkan kesejahteraan masyarakat.

Keadaan yang positif ini harus didukung oleh peningkatan layanan yang dilakukan oleh manajemen agar dapat menarik pengunjung untuk datang ke Taman Narmada, baik yang berasal dari masyarakat lokal, nasional, bahkan internasional. Padahal, jika dilihat dari fasilitas yang ada dalam Taman Narmada sendiri sangat bervariatif dan menarik. Misalnya, dari sudut 
pandang sejarah, Taman Narmada menyimpan kisah cerita yang menarik tidak hanya bagaimana bentuk dan model bagunan yang ada dalam areal tersebut yang bernuansa Hindu Bali, tetapi juga bagaimana proses akulturasi budaya antara budaya Sasak (Islam) dan Bali (Hindu) yang merupakan salah satu sisi yang menarik untuk diketahui oleh orang lain (Anonim, 2013).

Berdasarkan hasil evaluasi dari kegiatan pengabdian yang dilakukan sebelumnya, maka sasaran kegiatan harus diarahkan kepada unsur manajemen sehingga dapat mengatur tatakelola Taman Narmada, terlebih lagi bagaimana memberdayakan seluruh pegawai dari depan (front liner), tempattempat hiburan (public site), hingga situs-situs sejarah. Disamping tatakelola, masalah yang menunjang terlaksananya layanan prima kepada para pengunjung adalah masalah etika profesi, yakni bagaimana pegawai dibekali dengan etika yang santun yang berstandar internasional yang terintegrasi dengan nilai-nilai kearifan lokal. Persoalan yang mendasar lainnya adalah bagaimana membekali kemampuan para pengelola dari semua lini dengan keterampilan Bahasa Inggris yang memadai dalam memberikan pelayanan kepada para pengunkung, terutama pengunjung yang berasal dari
Eropa, Amerika, Australia, dan negara-negara asing lainnya.

Dengan memperhatikan persoalan tersebut, maka kegiatan pengabdian kepada masyarakat dengan judul "Pemberdayaan Pengelola Taman Narmada dengan Pola English-Integrated Service" dianggap penting dan relevan untuk dijadikan sebagai selah satu kegiatan pengabdian kepada masyarakat ini.

\section{METODE KEGIATAN}

Metode atau pendekatan yang digunakan dalam kegiatan ini adalah metode/pendekatan partisipatif. Metode ini berorientasi pada upaya peran serta sasaran secara langsung dalam berbagai proses dan tahap pelaksanaan kegiatan, mulai dari perencanaan, pelaksanaan, sampai pada evaluasi kegiatan. Sasaran tidak hanya bertindak sebagai objek kegiatan, tetapi juga sebagai pelaku kegiatan. Sementara itu, Tim Pelaksana hanya bertindak sebagai fasilitator dan motivator.

Secara operasional kegiatan Pengabdian Kepada Masyarakat ini dijabarkan dalam beberapa tahapan berikut.

\section{Tahap Konfirmasi Rencana Kegiatan dengan Sasaran \\ Konsfirmasi rencana} kegiatan akan disampaikan kepada sasaran, sekaligus membicakaran tentang tempat, waktu, serta hal- 
hal teknis lainnya supaya terbangun sinergisitas antara Tim Pelaksana dengan sasaran.

\section{Tahap Pelaksanaan Kegiatan}

Kegiatan pendampingan dilakukan dengan presentasi dan diskusi dan dilanjutkan dengan pendalaman materi melalui praktek (simulasi) di dalam kelas dengan pendampingan yang dilakukan oleh Tim Pelaksana. Materi pelatihan dalam kegiatan ini adalah prinsipprinsip pelayan prima, terutama yang berkaitan dengan etika berkomunikasi dengan para pengunjung yang terintegrasi dengan keterampilan berbahsa inggris.

\section{Evaluasi Pelaksanaan Kegiatan}

Evaluasi terhadap capaian target kegiatan dilakukan dengan menilai ketercapaian tujuan pengabdian. Teknik evaluasi dilakukan dengan pengamatan dan tanya jawab langsung kepada perseta palatihan, serta penilaian berbasis unjuk kerja (performancebased assesment).

Kegiatan Pengabdian kepada Masyarakat ini bertempat di Taman Narmada, Desa Narmada, Dusun Taman, Kecamatan Narmada, Kabupaten Lombok Barat. Lokasi Taman Narmada berada di tengahtengah puat Kota Kecamatan Narmada Secara umum, masyarakat objek sasaran kegiatan pengabdian ini merupakan masyarakat setempat yang menjadikan Taman
Narmada sebagai sumber pencaharian, yang bekerja sebagai staff di Taman Narmada.

\section{HASIL DAN PEMBAHASAN}

\section{Sosialisasi Kegiatan}

Koordinasi

rencana

pelaksanaan kegiatan disampaikan kepada kelompok sasaran dilaksanakan pada 6 April 2019. Pertemuan ini dihadiri oleh beberapa pengelola bersama dengan eksekutif manager dari Taman Narmada. Pertemuan ini bertujuan untuk menetapkan jenis dan metode yang digunakan dalam kegiatan tersebut. Hasil sosialisasi disepakati beberapa hal terkait dengan kegiatan yang dimaksud. Pertama, materi pelatihan harus sesuai dan disesuaikan dengan kemampuan awal kelompok sasaran. Kedua, waktu pelaksanaan diupayakan untuk dilaksanakan di hari libur sehingga tidak mengganggu hari kerja sasaran. Terakhir, diharapkan kegiatan ini dilaksanakan secara intensif dan berkala.

\section{Koordinasi Pelaksanaan Kegiatan \\ Pertemuan yang}

dilaksanakan pada 18 Agustus 2019 bertujuan untuk membicarakan halhal teknis terkait pelakanaan kegiatan, seperti, waktu, tempat, dan pola pelaksanaan. Koordinasi kegiatan ini dihadiri oleh Eksekutif Manajer Taman Narmada dan 
beberapa beberapa staff. Hasil pertemuan ini disepakati bahwa kegiatan dilaksanakan pada 22 Agustus 2019 yang bertempat di Bale Gede, salah satu bagunan aula yang berada di dalam kawasan Taman Narmada.

\section{Pendampingan \\ Layanan \\ berbasis English-integated service}

Pendampingan Pelayanan

berbasis English-Integrated service ini dilakukan dengan pendekatan komunikatif klasikal (Aziz dan Arafiq, 2016). Kegiatan diawali dengan memaparkan topik-topik Bahasa Inggris yang dibutuhkan oleh pengelola mulai dari petugas frontline (loket) hingga petugas backline (situs cagar budaya). Kesesuaian topik dengan kebutuhan masyarakat sasaran dapat menjamin kelancaran kegiatan dalam memenuhi kebutuhan masyarakat sasaran (Arafiq dan Gadu, 2001). Setelah selesai satu topik bahasan, dilalanjutkan dengan latihan komunikatif sehingga setiap peserta diminta untuk menggunakan dan mempraktekkan ungkapan-ungkapan Bahasa Inggris yang telah diberikan. Sebelum topik tertentu dikuasai, peserta belum diberikan topik yang baru.

Tahap selanjutnya adalah tahap pendalaman. Pada tahap ini, peserta diberikan bimbingan khusus secara intensif dan sistematis dalam mempraktekkan semua topik atau materi yang diberikan. Peserta dibagi dalam 2 orang (sepasang). Tim memfasilitasai beberapa pasangan dengan memberikan bimbingan dalam memaknai ungkapan-ungkapan, mengucapkan kata-kata, serta intonasi ketika melakukan praktek percakapan. Selama kegiatan ini semua peserta dapat melakukan sesuai dengan bimbingan. Bahkan beberapa diantaranya memiliki kemampuan dasar Bahasa Inggris yang cukup bagus sehingga setiap materi dan kegiatan pendampingan dapat dilakukan dengan baik dan sempurna. Namum demikian, masih ada beberapa peserta yang masih sulit dalam menerima maupun melakukan kegiatan sesuai arahan dan bimbingan tim pendamping. Hal ini disebabkan mereka merasa Bahasa Inggris itu betul-betul bahasa asing. Dengan kata lain, kesempatan itu merupakan kali pertama mereka berinteraksi secara langsung dengan Bahasa Inggris.

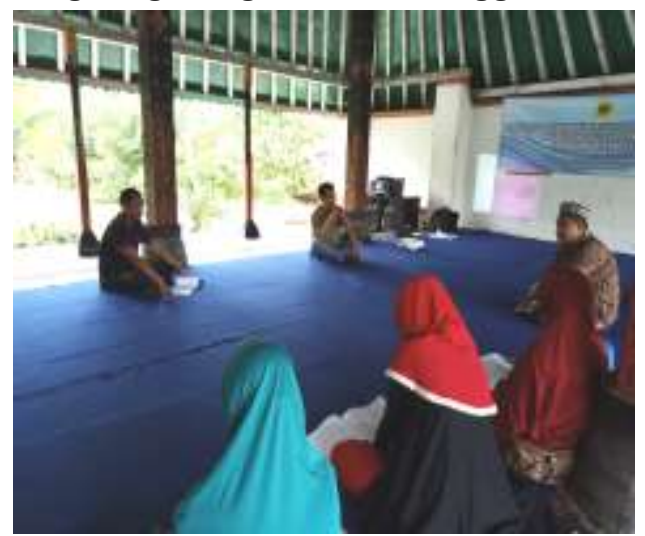

Gambar 1. Kegiatan Pendampingan Klasikal 
4. Evaluasi Palaksanaan Kegiatan

Evaluasi dilakukan dengan cara observasi (pengamatan) dan performance-based assement terhadap penampilan/keterampilan peserta dalam melakukan percakapan terhadap semua topik yang diberikan selama pelatihan, terutama terhadap dua jenis petugas yang secara langsung berinteraksi verbal dengan pengunjung. Berdasarkan hasil observasi tersebut, ditemukan bahwa secara umum, kamampuan perserta dalam berkomunikasi menggunakan Bahasa Inggris, khususnya topik-topik welcoming, dan percakapan-percakapan tentang perkenalan (introduction), petunjuk jalan (directions) cukup bagus. Lebih-lebih setelah mendapatkan pembimbingan.

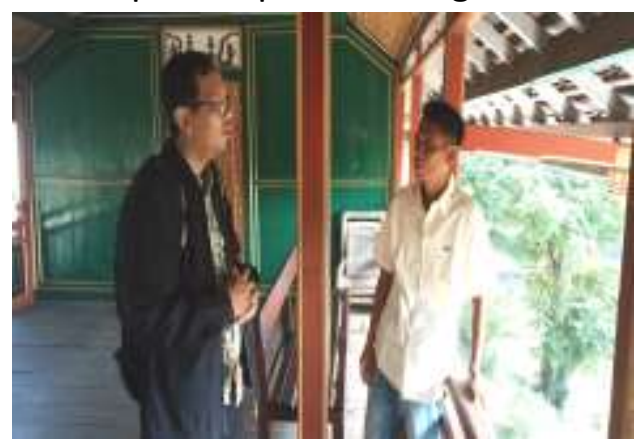

Gambar 2. Ujicoba keterampilan berbahasa Inggris pserta pelatihan

Hal lain yang diperoleh dari hasil pengamatan selama kegiatan adalah keseriusan dan ketekunan peserta selama mengikuti kegiatan sangat bagus. Hal ini menunjukkan bahwa peserta sudah mulai memiliki sikap positif terhadap
Bahasa Inggris. Sikap positif ini merupakan modal utama untuk dapat memotifasi peserta didik untuk terus menerus belajar mengembangkan dan meningkatkan kemampuan Bahasa Inggris mereka.

\section{KESIMPULAN DAN SARAN}

\section{Kesimpulan}

Kegiatan pendampingan pengelolaan Taman Narmada dengan pola English-integrated service sudah di dilaksanakan dan memiliki hasil yang sangat positif. Persoalan yang dihadapi oleh mitra (para staf pengelola Taman Narmada) yang berkaitan dengan pelayanan dengan menggunakan Bahasa Inggris secara umum sudah teratasi walaupun tidak sempurna.

\section{Saran}

Kegiatan pengabdian dalam bentuk pelatihan, pendampingan dan pembimbingan Bahasa Inggris komunikasi yang intensif bagi pengelola, pedagang souvenir, dan pihak-pihak lain yang berkecimpung dalam aktivitas pariwisata di Taman Narmada, perlu dilakukan dengan melibatkan sasaran yang lebih luas, mulai dari kantor depan (ticketing), obyek-obyek wisata, pasar seni, dan tempat parkir dalam waktu yang cukup lama ehingga betul-betul dapat membawa manfaat bagi sasaran. Disamping itu, perlu dilakukan pendampingan secara terus-menerus guna mendukung 
pembangunan sektor pariwisata di Taman Narmada.

\section{UCAPAN TERIMAKASIH}

Kegiatan pengabdian kepada masyarakat ini dapat terlaksana dengan baik berkat bantuan dan dukungan berbagai pihak. Oleh karena itu, ucapan terimakasih yang tak terhingga disampaikan kepada Rektor Universitas Mataram yang telah membiayai segala kebutuhan kegiatan pengabdian ini. Terimakasih yang sama disampaikan kepada Dekan FKIP Universitas Mataram yang telah mengizinkan Tim untuk melaksanakan kegiatan ini. Terimakasih yang berlimpah kepada Eksekutif Manajer, Bapak Kamaruddin, S.I.P., M.H. dan seluruh staff pengelola Taman Narmada yang telah kooperatif dan ikhlas menyediakan waktu, tenaga, dan fasilatas sehingga kegiatan pengabdian kepada masyarakat ini dapat terlaksana dengan baik.

\section{Daftar Pustaka}

Arafiq, Gadu P. 2001. Practical English for Tour Guide. Yayasan Kerya Wisata Mataram, Akademi Pariwisata Mataram.
Anonim, 2013. Profil Potensi Pariwisata Lombok Barat. http://dinaspariwisatalombok barat.blogspot.co.id/2012/03/ profil-pariw.isata-lombokbarat.html: Diakses 14 Maret 2018.

Anonim, 2016. Peta Kelurahan/ Narmada Lombok Barat. http://peta-jalan.com/-

Narmada-kab-lombok-barat/:

Diakses 14 Maret 2018.

Aziz AD, Arafiq. 2016. "Pendampingan Percakapan Bahasa Inggris Bagi Pedagan Asongan Di kawasan Wisata Senggigi". Jurnal Abdi Insani Universitas Mataram. Vol 3 No.2 September 2016.

Arafiq, Hanafi N, Mu'adz HM, Syahdan, Yusra K. 2019. "Pendampingan Aplikasi Buku Praktis English Conversation bagi Pedagang Souvenir di Pasar Seni Taman Narmada, Lombok Barat." Jurnal Abdi Insani Universitas Mataram Vol. 6 No.1 2019. 